\title{
EFFECTS OF ALCOHOLISM, MORPHINISM, AND BARBITURATE RESISTANCE ON INDUCTION AND MAINTENANCE OF GENERAL ANAESTHESIA*
}

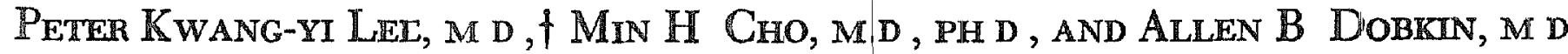 \\ With the technical assistance of Donald A CURTIS, B A
}

Pathology would remain a lovely science, even if there were no therapeutics, just as seismology is a lovely science, though no one knows how to stop earthquakes

H L MENCKEN (1880-1956)

Clinical impressions have indicated that alcoholics and drug addicts may require larger induction doses of thiobaibiturates, volatile anaesthetics, or nitrous oxide, and usually undergo a prolonged induction stage when diethyl ether is administered 12 The effect of ethanol on induction of diethyl ether anaesthesia was shown clearly by the expermental study by Abrev and Emerson in $1939^{3}$ It has also been shown in dogs and rats that the repeated prior administration of various narcotic analgesics reduces the duration of sleep with a thiobarbiturate ${ }^{45}$ In contradistunction, Moyers and Thayer reported, in 1962, that following chronic alcohol ingestion by dogs, "sleep" is produced with a "normal" amount of thiopental, but its duration is twice that of a conirol group of dogs ${ }^{6}$

This communication reports how ethanol-tolerant rats, dihydromorphinonetolerant mice, and barbiturate-resistant rats reacted to induction and maintenance of anaesthesia with diethyl ether, methoxyflurane, thiopental, methohexital, and a combination of methohexital and Innovar. is to attempt to clarify whether drug-tolerant rodents react any dufferently to general anaesthesia than non-tolerant rodents, and to evaluate the data as a guide to the management of anaesthesia in drug-tolerant humans

\section{Materials and Methods}

Five series of experiments were carried out

In the first series, 75 Sprague-Dawley, albino, male rats, weighing 80 to 100 grams, were divided into six groups of 12 or 13 rats in each All groups were fed water and dry food (Big Red ral food\$) for three days, then 20 per cent diethyl ether anaesthesia was given and control data for induction time and maintenance time were recorded by using the following rechmique Each rat was individually placed in a 2-litre capacity transparent jar An inlet tube which reached the bottom of the jar was attached to the outlet of an EMO vapourizer set at

"From the Anesthesiology Research Laboratory State University of New York, Upstate Medical Center, Syracuse, New York Supported by U S Public Health Service Grant No NB-03809-02 and a grant-in-aid from Abbott Laboratories, Chicago, Illinors

PPostdoctoral Research Fellow Presently Associate Professor of Anesthesiology, University Hospital, Taipel, Taiwan (Formosa)

\$ McNell Laboratones Incorporated, Fort Washington, Pennsylvanıa

§G L F Cooperative, Waverly, N Y 
20 per cent diethyl ether, and 6 litres per minute of oxygen was injected into the inlet of the vapourizer The jar had an outlet opening to the air with the same drameter as the orifice of the inlet tube In every test, the vapour was blown into the jar for exactly 10 seconds The induction time of anaesthesia was recorded in seconds, by stopwatch, from the moment the oxygen was turned on through the vapourizer untl the rat ceased to struggle and collapsed Then the rat was removed from the jar and left in room aur and the time interval was recorded from the moment of collapse until the rat was able to right itself and walk This tume interval was called the mantenance time Then, three groups were treated by a modification of the method described by Abreu and Emerson, ${ }^{3}$ giving intraperitoneal injections of 10 per cent ethanol once dally The first week, they were given $20 \mathrm{ml} / \mathrm{kg}$ dally, then the dose was increased to $40 \mathrm{ml} / \mathrm{kg}$ the second week and $60 \mathrm{ml} / \mathrm{kg}$ the thurd week The other three groups were held as controls and received injections of 09 per ent saline in the same volume The fourth week, 10 per cent ethanol in water was given to the rats as drinking water $a d l b b$ instead of giving intraperitoneal injections, while the control group were given 09 per cent salıne as drinking water

At the end of the first, second, and third week, the rats were given an anaesthetic with 20 per cent diethyl ether, as was done before beginning the ethanol injections At the end of the fourth week, the rats were given an anaesthetic with 15 per cent methoxyflurane, using the same technique as described above except that a calibrated Pentec vapourizer was used instead of the E MO vapourizer One day before they were given methoxyflusane, they received an anaesthetic with methohexital (05\%,30 $\mathrm{mg} / \mathrm{kg}$, intraperitoneal injection) and, one day after, they received an anaesthetic with thiopental $(1 \%, 30 \mathrm{mg} / \mathrm{kg}$, intraperitoneal injection)

The second series consisted of 77 Sprague-Dawley, male albino rats, weighing 80 to 100 grams They were divided into six groups with 12 or 14 rats in each and were fed with dry food (Big Red rat food) and tap water ad $l b$ for thee days, then 15 per cent methoxyflurane anaesthesia was given to all the rats, as described for the first series

The induction time and mantenance tume were recorded as the control data for all groups in this series Then, Group 1 was held as a control and fed dry food and tap water $a d l b$. The other five groups were fed with dry food and 10 per cent ethanol in water $a d l l b$ for three weeks The ethanol concentration in the drinking water was increased from 10 per cent to 15 per cent during the fourth and fifth weeks and to 20 per cent durng the sixth week $\mathbb{E}$ thanol was then withdrawn during the seventh week, when the rats were given tap water and dry food, as for the control group The amount of water and ethanol in water consumed by each rat was measured dally and the body weight was measured once weekly At the end of the first, second, and thrrd weeks, 15 per cent methoxyflurane anaesthesia was given At the end of the fourth week, 20 per cent diethyl ether anaesthesia was given and methohexital anaesthesia (05\%, 30 $\mathrm{mg} / \mathrm{kg}$, intraperitoneally) was given two days after the diethyl ether anaesthesia At the end of the sixth and seventh weeks, 15 per cent methoxyllurane anaesthesia was repeated and it was followed with 20 per cent diethyl ether anaesthesia 
and methohexital anaesthesia, one day and two days after the methoxyflurane anaesthesia, respectively

In the third series of experiments, 36 Sprague-Dawley, albino male rats, weighing 100 to 120 grams (mean 109 grams) were used Three groups of 12 rats were fed with Big Red rat food and tap water $a d l b b$ for three days, then they were given an anaesthetic with $30 \mathrm{mg} / \mathrm{kg}$ methohexital, intraperitoneally, in 05 per cent solution Feeding was continued as above for two days; then, the following day, they were given another anaesthetic with $30 \mathrm{mg} / \mathrm{kg}$ methohexital $(05 \%)$ together with $05 \mathrm{ml} / \mathrm{kg}$ Innovar (containing $05 \mathrm{mg} / \mathrm{ml}$ dehydrobenzperidol $+001 \mathrm{mg} / \mathrm{ml}$ phentanyl) The induction times and maintenance tumes for these two experiments were recorded as the control data

The three groups were then fed dry food and 10 per cent ethanol in water ad $l i b$ for three weeks During this time, the amounts of 10 per cent ethanol consumed by the rats were measured dally and therr body weights were measured weekly Then, the induction time and maintenance time of anaesthesia for methohexital + Innovar were determined The rats were deprived of ethanol for one week (water and dry food were given) Anaesthetics were administered again at the end of the fourth week

The fourth senes consisted of 36 male mic* with body weight of 22 to 24 grams These were divided into three groups of 12 mice in each They were fed Big Red rat food and tap water $a d l b b$ for three days, then milk ad lib (3 parts of water and 1 part evaporated milk) and dry food ( 1 gram per mouse per day) Methoxyflurane (15\%) anaesthesia was giveh after the first three days to all mice for control data Thiee days after the control anaesthetic, dihydromorphinone hydrochloride (DHM) was added to the milk of Groups 2 and 3, according to the method described by Shuster and associates ${ }^{7}$ The mice were anaesthetized, one at a time, as was done with the rats, using 15 per cent diethyl ether, 05 per cent $50 \mathrm{mpk}$ methohexital and 15 per cent methoxyllurane, at weekly intervals after the narcotic was added DHM was withdrawn following the anaesthetics at the end of the fourth week and the dry food and water $a d l b b$ diet was restored One week later, the anaesthetics were given again

In the fifth series of experiments, 42 albino 1 ats of 80 to 100 grams body weight were used They were fed with Big Red rat tood and tap watei for three days Then each rat was given 15 per cent methoxyflurane and 20 per cent diethyl ether, a day apart, using the same technique as described above The rats were then divided into two groups 14 rats were held as controls and the other 28 rats were given 05 per cent methohexital, $30 \mathrm{mg} / \mathrm{kg}$ body weight by intiaperitoneal injection, once daily for two weeks The control rats received $6 \mathrm{ml}$ of 09 per cent saline per kg of body weight, once daily, by intrapentoneal injection, which was the same volume of flund that the test group was receiving General anaesthetics with 20 per cent diethyl ether and 15 per cent methoxyflurane, a day apart, were given at the end of the second week The rats were left at rest without any injections for one week and then the two general anaesthetics were repeated a day apart

"C57BL/6J strain obtaned from Jackson Memorial Lab, Bar Harbor, Mane

tDILAUDID from Knoll Pharmaceutical Co, Orange, N J 
For each set of experiments, the mean value of the induction time, maintenance time, and the standard eirol of the mean were calculated and the data were analysed statistically using the chi square test and probability tables

\section{Results}

Senes 1

Data from the experments in Selles 1 are summanized in Tables I and II

In the ethanol-tolerant rats of Senes 1 , the induction time with diethyl ether vas significantly increased at the end of the first week At the end of the second and third weeks, the diethyl ether induction time was piactically the same as that for the initial andesthetic The mantenance time was not appreciably changed $\mathrm{m}$ any of the experments In the control group, induction time and mamtenance time with diethyl ether anaesthesia, at the end of the first, second, and thind weeks, were all about the same as for the initial anaesthetic

During the fouth week, when the test gioup of rats were given 10 per cent ethanol orally ad $l i b$ in place of drinking water, they consumed $300 \mathrm{ml}$ fluid per $\mathrm{kg}$ per day on the average The ethanol-tolerant lats then showed a little longer induction time and a shorter mantenance time with methohexital anaesthesia, ie, they were somewhat more iesistant to methohexital anaesthesia than the control group

The next day, when they weie given 15 per cent methoxytlumane anaesthesid, the induction time and mantenance time of the ethanol-tolerant rats were practically the same as for the contiol group and, the day following, when thiopental anaesthesia was given (1\%,30 $\mathrm{mg} / \mathrm{kg}$ body weight, intraperitoneally), the ethanol-tolerant rats showed a trend to a prolonged induction and maintenance time in comparison with the control rats However, the standard error was very large among the ethanol-tolerant rats, so that the difference was not statistically significant (see Table I)

Up to the end of the second week, ethanol-tolerant rats gained much more weight than the control rats-67 per cent vs 46 per cent (Table III) However, during the third week, the ethanol-tolerant rats gamed weight less rapidly and they soon fell behind in their werght gann, so that at the end of the study penod the total weight gain was 92 per cent for the ethanol-tolerant groups and 97 per cent for the control groups

The mortality rate of the rats in this series was high Fourteen rats died in both the control and the ethanol-tolerant groups during the first three weeks These deaths were attributed to the complications resulting from multiple intraperitoneal injections, since none of the rats died immediately after recovering from the anaesthetic tests

\section{Sernes 2}

Data from the experiments in Series 2 are summarired in Tables III, IV, and V

In general, the fluid intake increased as the body weight increased on a $\mathrm{kg}$ per day basis, with only slight fluctuations Water intake of the control group was greatest during the second week, with an average of $253 \mathrm{ml}$ per $\mathrm{kg}$ per day The ethanol-tolerant rats drank the greatest amount of fluid in the second week, 


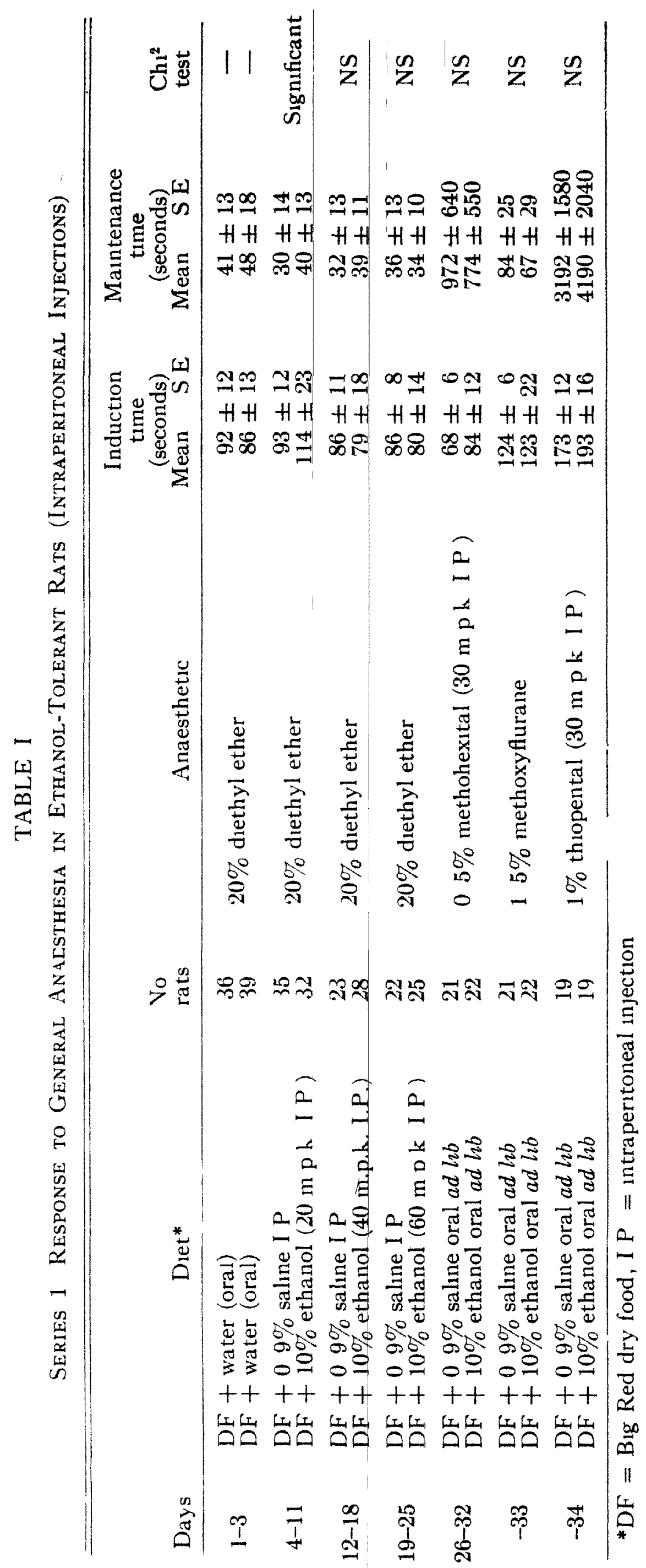


TABLE II

Average Body Weight of Rats in Series 1 (grams)

\begin{tabular}{lcc|cc}
\hline \hline & Initial weight & One week & Two weeks & Three weeks \\
\hline Control & 105 & $121(+14 \%)$ & $148(+40 \%)$ & $208(+97 \%)$ \\
Alcoholic & 92 & $121(+31 \%)$ & $154(+67 \%)$ & $177(+92 \%)$ \\
\hline
\end{tabular}

also, but this was much less in volume than what the control group drank The fluid intake, on a ml per $\mathrm{kg}$ per day basis, decreased as the concentration of alcohol was increased from 10 per cent to 15 per cent and from 15 per cent to 20 per cent The amount of fluid taken by the ethanol-tolerant rats almost doubled durng the seventh week when the ethanol was withdiawn and tap water substituted ( Table III)

During the first three weeks, in spite of the lesser amount of fluid and dry food taken, the ethanol-tolerant rats gained much more in body weight than the control rats Durng the following three weeks, the alcoholic rats gained less than the controls and, at the end of the sixth week, they gamed 24 times their initial weight while the control rats gained 26 times their initial weight Durnng the seventh week, the ethanol-tolerant rats again gained more than the controls, when they had tap water instead of ethanol to drink In both groups, there was no weight loss at any time during the period of the experiments (Table IV)

TABLE III

Average Fluid Intake of Rats in Serics 2 (ML/KG PLr day)

\begin{tabular}{|c|c|c|c|c|c|c|c|c|}
\hline & \multicolumn{8}{|c|}{ Day } \\
\hline & 4th (control) & 11 & 18 & 25 & 32 & 40 & 50 & 58 \\
\hline \multirow{3}{*}{$\begin{array}{l}\text { Control } \\
\text { Alcoholic }\end{array}$} & 90 & 190 & 253 & 177 & 123 & 114 & 160 & 230 \\
\hline & 102 & 127 & 140 & 116 & 104 & 107 & 81 & 154 \\
\hline & Water & \multicolumn{3}{|c|}{$\begin{array}{c}10 \% \\
\text { ethanol }\end{array}$} & \multicolumn{2}{|c|}{$\begin{array}{c}15 \% \\
\text { ethanol }\end{array}$} & $\begin{array}{l}20 \% \\
\text { ethanol }\end{array}$ & Water \\
\hline
\end{tabular}

TABLE IV

Average Body Weight of Rats in Series 2 (Grams)

\begin{tabular}{lrrrrrrrrr}
\hline \hline & \multicolumn{10}{c}{ Day } \\
\cline { 2 - 11 } & 4 th (control) & 11 & 18 & 25 & 32 & 40 & 50 & 58 \\
\hline Control & 89 & 113 & 141 & 182 & 243 & 263 & 313 & 325 \\
Alcoholic & 88 & 116 & 140 & 195 & 220 & 235 & 264 & 300 \\
\hline
\end{tabular}

All of the surviving rats remained in good condition and healthy throughout the experments However, we observed that the ethanol-tolerant rats' fur was more shiny and they were more active and offensive when disturbed or handled durng the anaesthetic tests There were no deaths during the first three weeks in any group of rats Four among the 14 control rats died in the fourth week (28\%), then there were no deaths to the end of the tests Eleven among 63 of the 
ethanol-tolerant rats died (17\%) 2 in the $\|$ ourth week, $3 \mathrm{~m}$ the fifth week, $1 \mathrm{~m}$ the sixth week, and 5 died during the week after the ethanol was withdrawn

Induction of anaesthesia with 15 per cent methoxyflurane in the ethanoltolerant rats was very stormy and the incluction time was piolonged after the first week, but the difference in induction time in comparison with the control group did not become statistically significant until the anaesthetics were given at the end of the second and third weeks On the other hand, the maintenance tume remained practically the same thioughout The contiol lats showed no appreciable change in serial response to induction time or maintenance time during the six anaesthetics with methoxylunane, although the mantenance time seemed to shorten in the control group of lats as they giew bigger, whereas there was no consistent difference in the ethanol-tolerant 1 ats At the end of the seventh week, after the flud fed to the ethanol-tolerant rats was agam tap water, the induction time and mantenance time of anaesthesia were virtually the same for the control and the ethanol-tolerant rats (see Table V)

When 20 per cent diethvl ether anaesthesid was given to the rats at the end of the fourth week and sixth week, there was no apprecrable difference in response between the ethanol-tolerant rats and the contiol rats in both the induction time and maintenance time At the end of the seventh week (the week the ethanol-tolerant rats drank tap water instead of ethanol) there was again no difference between the alcoholics and the controls (see Table V)

When methohevital anaesthesid $(05 \%, 30 \mathrm{~m} \mathrm{pk}$, intraperitoneal) was given at the end of the sixth week, two among 22 of the ethanol-tolerant rats refused to sleep and the others showed longer induction time and shorter mantenance time We had the impression that these rats were resistant to methohexital andesthesia However, this effect was not statistically significant There was also no statistical difference in the induction tune and maintenance time between the ethanol-tolerant rats and the control group of rats during the methohexital anaesthetics at the end of the fourth and seventh weeks, although one out of 61 and two of 22 rats, respectivelv, did not sleep when thev recerved the methohexital

\section{Sernes 3}

Data from these expei iments are shown in Table VI

During the three-week period that these rats were fed 10 per cent ethanol orally, they consumed an average of $116 \mathrm{ml}$ per $\mathrm{kg}$ per day and, at the end of the third week, their mean weight had increased from 109 to 250 grams In all respects, their reaction to the feedings was similar to that observed in the second series of experments There was no appreciable alteiation in their response to the anaesthetic combination of methohexital and Innovar anaesthesia in comparison with the control test after three weeks of ethanol intake Durng this time, 5 rats died During the one week of ethanol deprivation, 5 more rats died, but there was again no significant alteration in their response to the injection of the anaesthetic drugs

\section{Sernes 4 Dihydromomphinone Tolerant Muce}

The data from these experiments are summarized in Table VII 


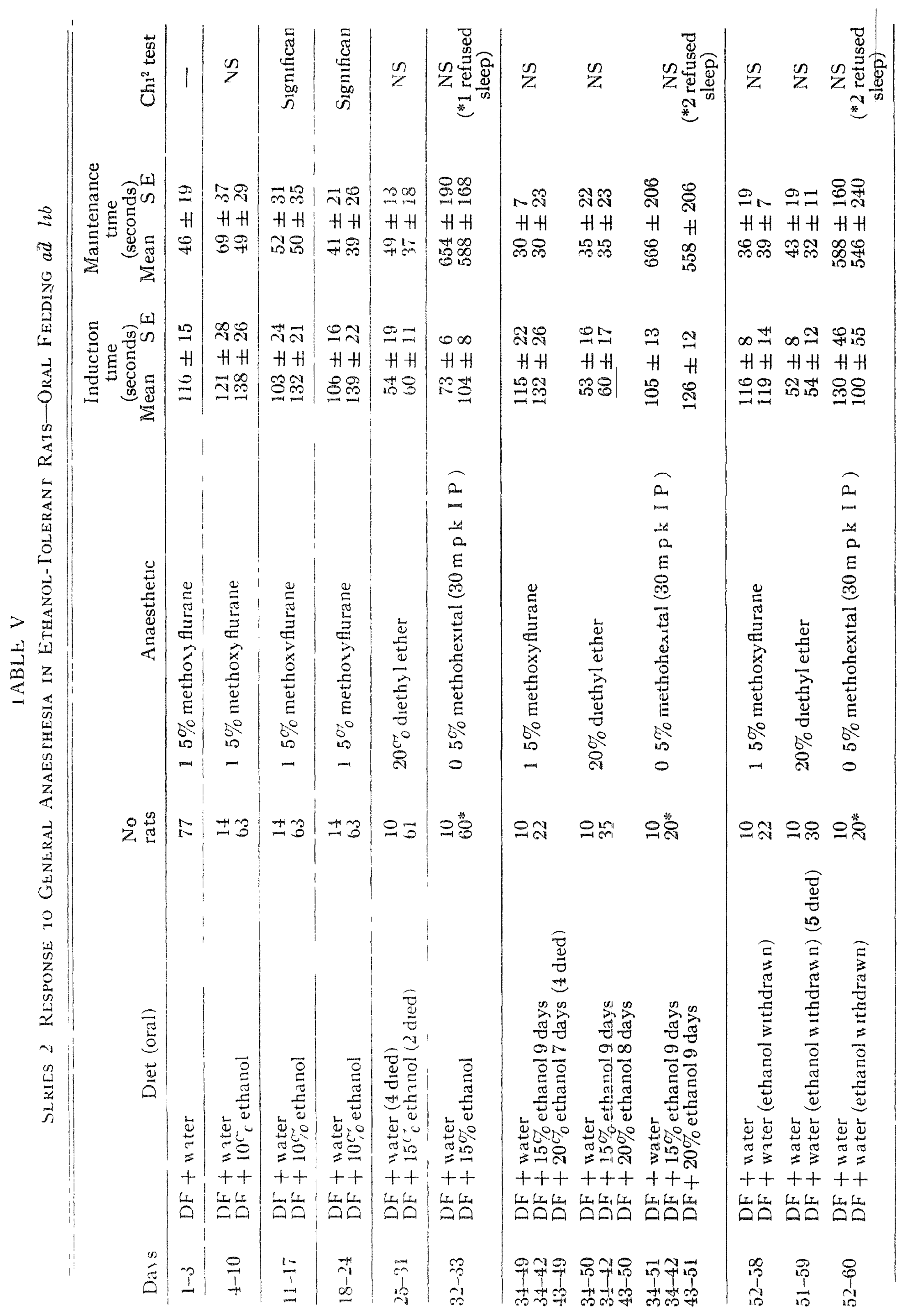




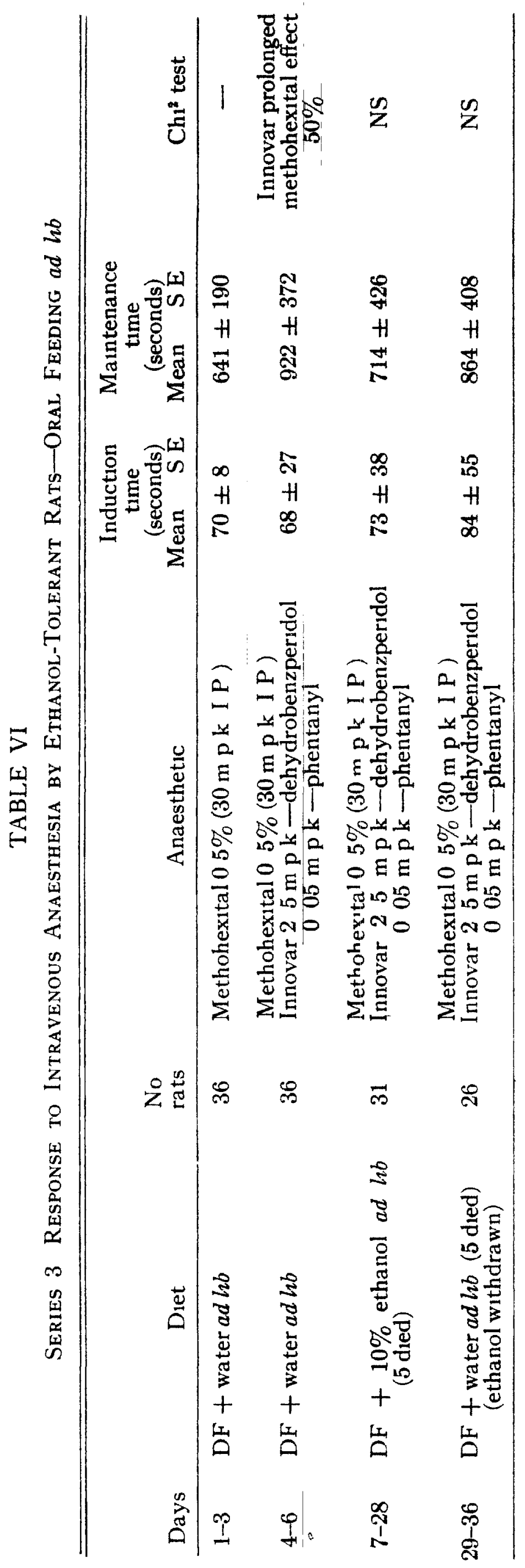




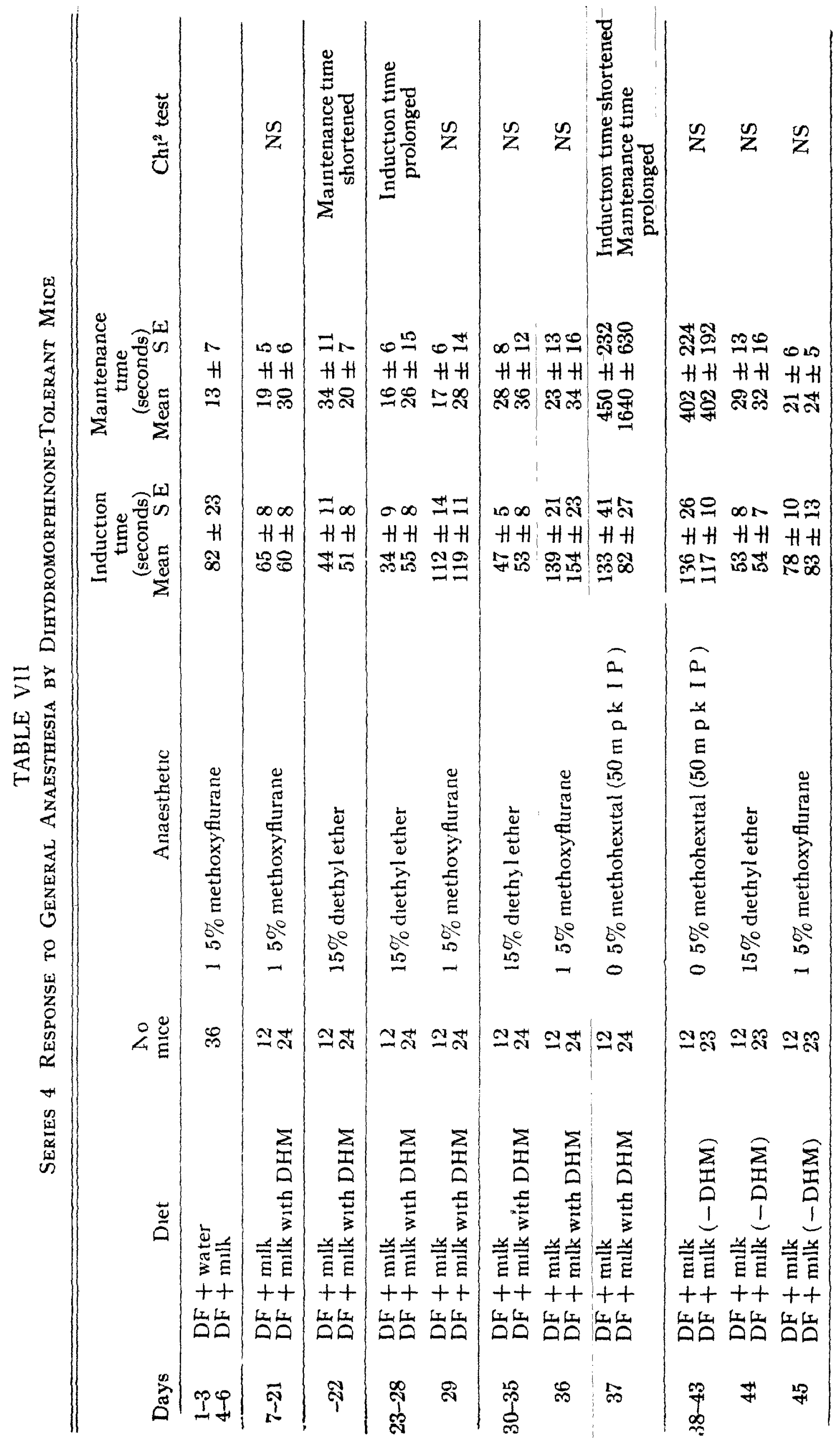


The mice were allowed to take dry food and fluid during the night and the anaesthetic tests were carried out in the afternoon to avoid the acute effects of DHM

For the first three days after DHM was added to the milk, the test group of mice took less than the contiol group However, the amount of milk taken increased day by day and reached approximately the same level for all groups on the fourth day The lowest intake of DHM in the milk was $68 \mathrm{mg}$ per $\mathrm{kg}$ per day At the end of the first week, the average intake of milk was 24 grams, so the average intake of DHM reached ah average of $80 \mathrm{mg}$ per $\mathrm{kg}$ per day The milk consumption was about the same for the control group of mice, but the DHM-fed mice gained more body weight, had shinier fur, and carried their tails higher and more erect than the controls

After the second week, the DHM-treated mice had, on the average, a somewhat shorter induction time and longer mantenance time with 15 per cent methoxyflurane anaesthesia, but these alterations were not statıstically significant Anaesthesia with 15 per cent diethyl ether the following day caused no appreciable statistical difference although induction time appeared longer and maintenance time shorter

After the third week of treatment both methoxyflurane and diethyl ether anaesthesia induction and maintenance times were prolonged, but again the differences from the control tests were not sufficient to be significant

During the third and fourth weeks of $\mathrm{DHM}$ treatment, the mice began losing weight and they lost the shiny appearance of therr fur They became lethargic, ataxic, and their tails drooped However, the apparent lengthening of induction times and mantenance times with both methoxyflurane and diethyl ether did not reflect the above changes because the mice held as controls had a rather similar lengthening of the anaesthesia time

At the end of the fourth week, when methohexital anaesthesia was induced, there was a shorter induction time and prolonged maintenance time in the DHM-tolerant mice These changes were statıstıcally highly significant, indicating that the narcotic-tolerant mice were more sensitive and susceptible to methohexital anaesthesia than were the controls

One week after the withdrawal of DHM, the narcotic-tolerant mice regained their body weight, healthy appear ance, and activity, and appeared generally the same as the control group of mice The induction times and maintenance times of anaesthesia with diethyl ether, methoxyflurane, and methohexital anaesthesid in the tolerant mice reverted to close proximity to those of the controls

All of the mice survived the expermments except one mouse in the addicted group which died one day after withdrawal of DHM

\section{Series 5 Barbiturate-Tolerant Rats}

Data from these experments are shown in Table VIII

The rats which recerved the darly injections of methohexital developed remarkable resistance to the barbiturate On the eighth day of the intraperitoneal injections, two among 28 rats refused to sleep and the maintenance time of the remaining rats was significantly shortened in comparison with the response to 


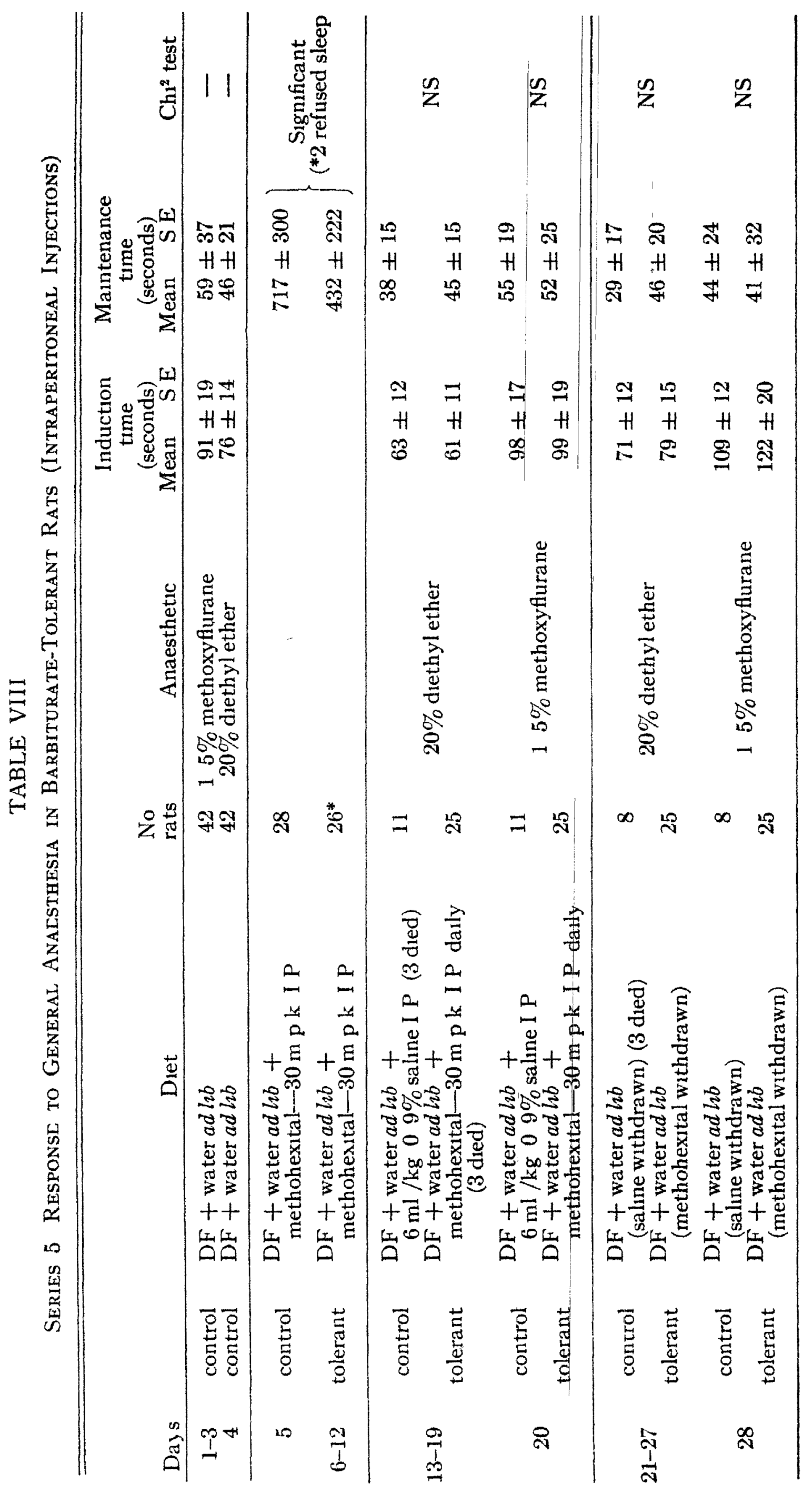


the first injection However, induction and maintenance of diethyl ether or methoxyflurane anaesthesia showed no difference to that for the control group The induction time and mantenance time of diethyl ether and methoxyflurane anaesthesia, one week after withdrawal of the methohexital imjections, also showed no difference from the control group or from the original control tests obtaned before starting the methohexital injections

Three of the control group and thre $\epsilon$ of the barbiturate-resistant group of rats died durng the second week of daily intraperitoneal injections of saline and methohexital respectively Three more rats died in the control group during the third week whereas none of the methohexital-resistant rats died after the drug was withdrawn

\section{Discusston}

Addiction to ethanol, barbiturates, and narcotic analgesics is an alarming problem in America, not only because it is estimated to affect directly as much as 1 per cent of the adult population, but also because it is not fully accepted as a disease entity that requires medical attention

On account of the sociological and psychological implications, it is often difficult for the anaesthetist to elicit a reliable history of addiction to any drug from his patients The problem seems to loom even larger because the patient in the hospital awating a surgical proceduie is almost invariably deprived of his favourite medication and the usual sign of withdrawal such as anxiety, the feeling of weakness, tremors, excessive perspiration, anorexia, naused, vomiting, fever, tachycardia, delurum, and hallucinations may one and all be confused with either a simple anxiety reaction to the pending surgical operation, or with effects of the disease for which the patient was admitted to the hospital These reactions may confound attempts at diagnosis or therapy and can augment the difficulty of estimating the optimum anaesthetic technique

There is a particular matter that must be weighed in evaluating the validity of experimental studies on this subject humans who become tolerant to ethanol, morphine, or barbiturates usually have become habituated to these either on account of a chromic medical indication for the diugs that are used, or because of a psychic defect which led to repeated prescription of one of the "escape" drugs The initial resistance to induction of andesthesid by such people may therefore be related to a greater degree of anxiety to a stress situation than might be expected in a normal individulal At a later stage of tolerance, or established dependence, this difference may well be suppressed as long as the required drugs are avalable The experimental anmal cannot be provided with this preliminary chromic need or psychic defect easlly and, of course, the development of habituation to a drug is not made by the animal's choice Herem lies one of the fundamental problems in designing a study involving the response of a drug addict to an added stiess situation

The specific problem that faces the anaesthetist in studying this subject may be considered in two steps In the finst, he must gain a clear understanding of the effect of the acute interaction of each one of the major anaesthetics with simultaneous administration of ethanol, a narcotic analgesic, or a barbiturate, 
because each one of these substances can enhance the physiological depression of respiration, circulation, and neuromuscular transmission that usually accompanies the induction of general anaesthesia At the same time, they might suppress the detoxication mechanısms of the body, and hence delay metabolic degradation and/or excretion of one or the other In the second step, the anaesthetust must learn whether, durmg the development of progressive stages of dependence or tolerance to an addicting drug, there is any alteration in their rate of metabolism and, if so, whether such an alteration can enhance or depress the effect of an anaesthetic drug

At this point, it is well to review the usual sequence of events during the development of tolerance to the sedative-type drugs ${ }^{8}$ This will serve as a baseline in discussing and evaluating the responses that appeared when a ge anaesthetic was added at different stages (see Fig 1)

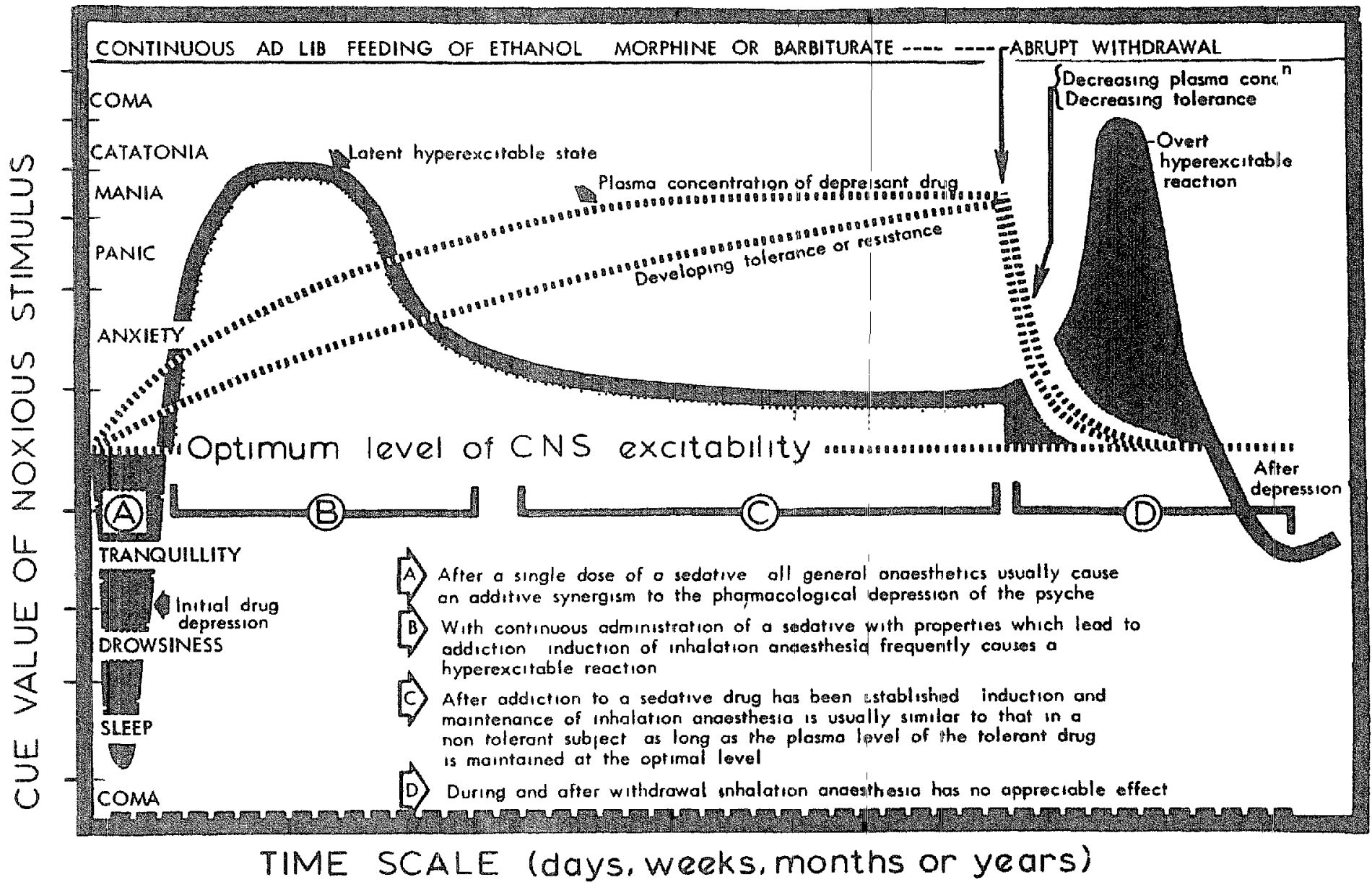

Figure 1 Responses during progressive development of tolerance to depressant drugs and to withdrawal (modified from $\mathrm{M} H$ Seevers)

The usual initial effects following absoiption of an effective dose of a sedativetype drug, under normal conditions, are general depiession, tranquillity, drowsiness or sleep, andgesia (in the case of the appropriate drugs), and motor weakness There is a sharp depression in the normal integiated level of nervous excitability provided that the subject is not disturbed With some sedative drugs, there appears with the first dose a rather marked increase in the latent hyperexcitable state-that is, the response to noxious stumulation is characteristically cvident as unusual restlessness, umuly conduct, and bizarre behaviour As continued ingestion of a sedative drug takes place, tolerance (or resistance to 
subjective and objective effects) begins to develop, and this accelerates as the dose is increased, or when the interval between each intake is shortened Overt signs of drug depression soon subside and, by the time maximal tolerance has developed, vutually no depression is evident, although certain vital organs may retain sensitivity to the noxious effects of the drug Wikler has stressed that the development of maxımum tolerance (and dependence) requires the maintenance of a continuous and uninterrupted optimal plasma concentration of the drug at all times If the addict is given unlimited access to the drug, he adjusts the quantity and frequency of administration to keep pace with the development of tolerance and prevents even the eallest signs of abstinence On the other hand, if the drug is given or is avallable at once-daily intervals only (as has been reported in experimental attempts at producing addiction in the past), it is unlikely that true tolerance and dependence can always be attained unless an adequate plasma level persists unt th the following dose is provided ${ }^{9}$ As tolerance to the drug increases, the state of latent hypesexcitability of the central and peripheral nervous system increases rapidly at first, but as the optimum plasma level of the drug is reached, latent hyperexcitability falls off, but it remains at a somewhat higher level than normal At this stage, the subject is said to be physically dependent upon the drug and will behave in a normal way even under stress as long as the requred drug is taken in adequate amounts Overt manifestations of central nervous system urritability and a hyperexcitable reaction only appear if an antagonistıc drug is given ( $\mathrm{g} g$, ethanol-disulfiram, morphine-nalorphine), or if the drug to which the subject is fully tolerant is suddenly withdrawn Onset of the overt reaction to withdrawal depends on the rate of antagonism or elimination of the drug becoming manifest when the plasma level has reached almost zero The reaction may remain intense for several days This is known as the abstinence reaction The interesting pharmacological aspect of the acute ieaction to abstinence is that it is most intense after virtually all tolerance has been lost, and this coincides with the time that the drug has been completely eliminated from the tissues of the body If, at this time, the plasma concentration of the dependent drug is restored rapidly to the previous optimal level, death from severe depression may occur Death may also occur from severe "after-depression" following acute ethanol, morphine, or barbiturate withdrawal

Effect of Ethanol

The propensity of acute ethanol ingestion to synergize (additively) the depressant and lethal effect of sedative drugs has been shown clearly by Melville, Eerola, and others, and is now well known ${ }^{10-16}$ Most of the depressant drugs ale metabolized by enzymes present in the microsomal fraction of the liver In the case of ethanol, its normal breakdown by alcoholic dehydrogenase to acetaldehyde and the subsequent oxidation to acehc acid, carbon dioxide, and water (which produces energy) occurs at the rate of approximately 10 per cent per hour Simultaneous administration of glucose and insulin seems to accelerate the metabolism of ethanol in the body On the other hand, many of the hypnotic 
sedative drugs evidently delay this process Therefore the blood and tissue levels of both sedative substances are sustained, producing a longer period of depiession of respiration, reflex activity, and other vital piocesses The depression of respiration produces progressive respiratory and metabolıc acidosis, marked by the accumulation of lactic acid, which, in turn, sustans and augments the depressant effect of the barbitunates on vital organs 171818

\section{Effect of Narcotuc Analgesics}

When a narcotic analgesic is administered orally, serious toxicity rarely occurs even with relatively large doses because most of the ingested drug is probably destroyed or conjugated while passing through the portal circulation, so that the amount of drug that becomes avalable systemically is not sufficient to exhibit appreciable physiological depression 20 The acute parenteral administration of narcotic analgesics can, by themselves, cause severe respuratory depression and circulatory instability, even in a relatively small dose, if the subject is not well, ${ }^{21}$ but a healthy person tolerates these drugs without gross evidence of physiolog $\Perp c a l$ depression ${ }^{22}$ and narcotics such as morphine and meperidine do not aculely cause an appreciable prolongation of anaesthesia with thiopental ${ }^{23}$

Woods and associates showed the effect of admunstering large quantities of morphine to tolerant and non-tolerant dogs Approsimately 40 per cent of an administered dose appears as conjugated drug in bile within a few hours This is ultimately reabsorbed from the intestine and excreted in the urine, so that 75 to 80 per cent of the administered dose ( $15 \%$ free and 60 to $65 \%$ conjugated) is excreted in 48 to 72 hours of the remaining fraction, 5 to 10 per cent is recovered in faeces, leaving about 10 per cent unaccounted for Morphine monoglucuronide, which they believe is pharmacologically inert, was identified as one of the principal conjugates There were quantitative differences in the amount of the conjugate in the urine between tolerant and non-tolerant dogs, untıl maximal tolerance had developed, after which there was no longer a difference They concluded that the observed initial difference in gross handling of morphine in the body is not a significant factor in the understanding of tolerance In earlier work, in which they analysed the tissues of tolerant and mon-tolerant rats, dogs, and monkeys, they failed to reveal a significant differentidl accumulation of morphine in any vital tissues except possibly the spleen and thyroid At the time the plasma concentrations were at therr peak, extremely small amounts were present in the brain and, after 48 to 72 hours, there was virtually no morphine detectable in tolerant as well as non-tolerant anımals Thus, there is no basis for the concept that tolerance might be related to an increased capacity of the body to detoxify or to distribute differentially a drug to which tolerance has developed There remains only the possibility that a product of detoxication selectively accumulates in or on neurons, which produce the state of hyperexcitability that is noted particularly at the tme of withdrawal Changes due to epinephrine and histamine release or mhibition of various enzymes have not been acceptable explanatrons by Seevers and Wood, who still adhere to the "dual action hypothesis"tolerance being described as an acquired resistance to narcotic effects and 
dependence being due to the cumulatwe effects of a longer-lasting direct excitation, following which the affected cells become sensitized rather than tolerant to this effect ${ }^{24-27}$

In the non-tolerant human subject, a therapeutic dose of meperidine, administered intravenously, disappears rather rapidly from the plasma during the first two hours as it is redistributed to the body tissues Very little is excreted unchanged in the urine $(<5 \%)$ Most of it is metabolized by demethylation and de-esterification This biotransformation and deactivation occurs at a rate of 10 to 20 per cent per hour ${ }^{28}$

Patients who become tolerant to the parenteral administration of narcotic analgesics do not appear to metabolize these drugs any more rapidly than nontolerant individuals, according to Burns, who suggested that in the development of tolerance to such drugs, the body does not acquire an increased capacity for its inactivation, but rather that some form of cellular "immunity" to the drug must play an important role ${ }^{29}$ Therefore, enhanced metabolic transformation does not appear to be an important factor in the development of tolerance to narcotic analgesics and whatever alteration occurs probably does not affect the interaction with anaesthetic drugs On the other hand, Dundee showed that daily administration of narcotic analgesics tends to cause resistance to anaesthesia with thiobarbitưrates administered intraperitoneally in dogs He found the same thing when the narcotic analgesics were given intramuscularly to rats ${ }^{30}$ Effect of Ultra Short-Acting Barbiturates

Brodie and associates showed that following thiopental administration the plasma level falls sharply at first, due to its rapıd distribution into body tissues, with the greater part passing into the fat depots Then, there is a much slower decline in the plasma concentiation which represents its biotransformation to carboxylic acid It appears to be excreted at the rate of 10 to 15 per cent per hour ${ }^{31}$ The acute administration of a very short-acting barbiturate presents many problems if one seeks specific inforrnation as to how quickly emergence from anaesthesia can occur, because no consistent relationship has been demonstrated between the plasma, brain, and fat concentration and the depth of anaesthesia, ${ }^{32}$ and emergence from anaesthesia often occurs at a higher plasma level after large doses than after smaller ones ${ }^{33} 34$ Nevertheless,s, tolerance has been demonstrated with ultra short-acting barbiturates by Green and Koppany ${ }^{4}$ Dundee stated that a minimum of thrice-weekly intravenous administration of thiopental to the dog leads to a 40 per cent decrease in the duration of sleep by the end of the third week, but he did not present supporting data ${ }^{35}$ However, the experiments by Hubbard and Goldbaum leave little doubt that rodents become tolerant to the dally administration of thiopental in 5 to 6 days, as evidenced by a 50 per cent decrease in sleeping time Based on tissue analysis, they showed also that the tolerance mechanism| appears to be one of adaptation to higher thiopental tissue levels and not to either an increased rate of excretion or destruction of thiopental ${ }^{36}$

Little information has appeared to explain why methohexital might be metabolized more rapidly in the body than thiopental, although there is no doubt that it is substantially more potent ${ }^{37}$ and somewhat shorter in its duration of 
action ${ }^{38}$ While tolerance can develop with single dally administrations of methohexital, as we have shown in the above experiments, a cumulative effect is more likely to occur with thiopental unless longer intervals are allowed between injections ${ }^{5}$

\section{Effect of General Anaesthesia in Ethanol-Tolerant Rodents}

We found that producing ethanol-tolerant rodents by dally intraperitoneal injections was an effective method because tolerance was developed quickly and objective psychic signs, such as increased excitability, were apparent When ethanol-tolerant mice are prepared for measuring the response to inhalation anaesthesia, they may show almost complete recovery within a few seconds after exposure to the same tension of an anaesthetic vapour as will cause non-tolerant mice to remain apparently deeply anaesthetuzed Abreu and Emerson therefore established the necessity for defining an induction end-point as that time at which the righting reflex is lost for at least 30 seconds ${ }^{3}$ We used rats instead of mice for this phase of the study because they are larger, easier to work with, less likely to die from multiple intraperitoneal injections, and we found that a fixed period of exposure to 20 per cent diethyl ether of 10 seconds was unlikely to allow sudden early "awakenıng" in ethanol-tolerant rats,

Using the technique described in the first series of experiments, we confirmed the reported observation that induction of anaesthesia with diethyl ether in ethanol-tolerant rats is prolonged and stormy, ${ }^{3}$ but there was no appreciable effect on the duration of maintenance of anaesthesia in the earlier stages of habituation When the daily consumption of ethanol was increased to that which would exceed approximately one quart of whiskey $1 \mathrm{n}$ a $70 \mathrm{~kg}$ man, this effect disappeared and there was even a trend to an apparent decrease in the induction time of diethyl ether anaesthesia, again, with no effect on the duration of maintenance In carrying the experiment a step further, the subsequent offering of ethanol orally to rats tolerant to a high blood level of ethanol did not affect their response to inhalation anaesthesia with methoxyflurane or the intraperitoneal administration of methohexital or thiopental, in comparison with rats fed water Besides the possibility outlined above and in $\mathbb{F}$ igure 1 , one other plausible explanation for a stormy and prolonged induction of anaesthesia with diethyl ether is that ethanol may be present in the tissues, even 24 hours after mjection, which might confer a higher affinity for ether and, so, slow induction, assuming all other things were the same between the control and ethanol-tolerant rats ${ }^{3}$ However, if this were a factor, the same response should have been apparent during the later stages of the test

In comparng the growth of rats, we were tempted to attach significance to the more rapid weight gain during the development of ethanol tolerance, but the biological signficance is much less in view of the much higher calonic intake supplied by the ethanol itself 18

In onder to avoid the relatively high mortality due to multiple intrapentoneal injections in the first series, we elected in the second and third series of experments to feed the rats the ethanol solution orally By using this procedure, we expected also to satusfy the requirements outlined by Wikler that 
assure the development of true tolerance and dependence ${ }^{\ominus}$ As occurred with the administration of diethyl ether andesthesia in the first series, induction of anaesthesia with methoxyflurane was stormy and somewhat prolonged durng the first few weeks, but the mantenance period of anaesthesia was unaffected When diethyl ether anaesthesia was administered after the fourth and sixth weeks, there was again no appreciable difference in the ethanol-tolerant rats The intraperitoneal administration of methohexital after the fourth, sixth, and seventh weeks, on the other hand, showed some difference in the ethanol-tolerant rats They seemed to be more resistant to the anaesthetic in that the collapse occurred a little later and maintenance was somewhat shorter The differences in both of these aspects was relatively small of little more significance, perhaps, was the observation that one rat of 61 , after the fourth week, and 2 rats of 22 , after the sixth and seventh weeks, respectively, were completely resistant to the methohexital, whereas no such effect was observed among the non-tolerant rats These observations hardly lend strong support to the finding of "acquired tolerance" that might occur with barbiturates, ${ }^{\beta 0}$ but it is a possible explanation for the changes we observed

In the third series of experiments, the original intent was to determine the effect of Innovar anaesthesia in ethanol-lolerant rats However, we were unable to induce anaesthesia in the rats during the preliminary experiments even with a very large dose of Innovar It was decided, therefore, to use a combination of Innovar with methohexital The combination prolonged the maintenance time of anaesthesia over that produced by methohexital alone by approximately 50 per cent After ethanol tolerance was established, there appeared to be a trend to the development of resistance, as was seen when methohexital was used alone in the second series However, there was considerable variation in the sleeping time, which annulled the biological significance that might be attributed to the change When ethanol was withdrawn for one week, the maintenance time for anaesthesia approximated that seen at the beginning of the experiment During this series of experiments, the anaesthesia induction times varied more than was seen in the second series. This may have been due to the different rates of onset of action of the three ingredients present in the anaesthetic mixture (methohexital, dehydrobenzpendol, and phentanyl)

\section{Effect of General Anaesthesia in Morphine-Tolerant Rodents}

In previous studies of addiction to opiates, morphine (by intraperitoneal injection) was the drug that was used commonly with mice, although it was recognized that the analogy for morphine addiction in mice was far from perfect Morphinized mice show a decrease in resistance to diethyl ether, which is the opposite response to that seen with ethanol-tolerant mice ${ }^{3}$ We chose to administer dihydromorphinone to mice, in the fourth senes of experiments, because the recent work of Shuster and associates showed that a pure strain of these rodents becomes tolerant within a few days to the analgesic and excitant effects of the narcotic if they are fed the drug in dilute evaporated milk By this method, narcotic-tolerant mice could be maintained in good physical condition, for a month or more, while drinking 50 to $70 \mathrm{mg} / \mathrm{kg}$ of dihydromorphinone dally 
Physical dependence is demonstrable in these mice because they lose as much as 15 per cent of their body weight overnight as soon as the narcotic is withdrawn from their milk feedings, just the same as occurs in man. ${ }^{7}$

While rodents become more excitable and difficult to handle because of their viciousness as they attain tolerance to ethanol, they become less excitable when tolerance to an opıate develops Nevertheless, in the dihydromorphinonetolerant mice, induction of anaesthesıa with diethyl ether was prolonged much the same as was seen in the ethanol-tolerant rats There was also a trend towards longer induction and maintenance times with methoxyflurane On the other hand, we observed a shortening of induction time and a striking increase in the maintenance time of methohexital anaesthesia That is, there appeared to be an additive synergism between the narcotic and the barbiturate, as one expects clinically The difference from the controls disappealed after the narcotic was withdrawn for one week This observed response to the very short-acting oxybarbiturate is rather different from the effect of narcotics combined with thiopental and thioamylal as described by Dundee ${ }^{30}$ However, he noted that withdrawal of narcotics restored the usual response to anaesthesia with barbiturates, as we did

\section{Effect of General Anaesthesia in Rodents Tolerant to Methohexital}

Whether true tolerance and dependence can be produced by dally administration of the very short-acting barbiturates is not clear in man, even though such an effect has been described frequently in animals and has been clearly proved with longer-acting barbiturates by Fraser and Isbell ${ }^{39}$ The term resistance has been used by Dundee, in this case, to describe a state which is analogous to acquired tolerance to narcotics ${ }^{5}$-and which Seevers defined as "the partial or complete resistance of immunity to quantities of these substances which would otherwise dimmish or completely abolish the functional activity of certain neurophysiological and other mechanisms" respect to the thiobarbiturates that although resistance to the hypnotic effect does appear with chronic administration, the liver and the myocardium may at the same time become more sensitive or specifically depressed ${ }^{5}$ In the fifth series of experiments reported above, we used methohexital to produce tolerance or resistance because' thiopental causes a high mortality in rats on account of its cumulation, unless the intervals between injections are increased to more than 30 hours Even though we observed a marked reduction in the sleeping time of the rats in response to the dally administration of methohexital, they reacted to inhalation anaesthesia with diethyl ether and methoxyflurane in much the same way as the rats used for controls

Untıl recently, no more plausible reason was worked out to explain why resistance or tolerance develops to oxybarbiturates such as hexobarbital and methohexital than for thiobarbiturates, ethanol, or the narcotics Tissue immunity, adaptation to higher tissue levels, and an increased rate of detoxication are attractive explanations

Burns and his associates have now shown that even though there is a marked species difference in the rate at which oxybarbiturates are metabolized (rodents 
$>$ man) and that many factors influence the rate at which the enzymes in the liver microsomes metabolize oxybarbiturates, the administration of certain drugs can speed up markedly the metabolism of other drugs The oxybarbiturates appear to be especially active in stimulating the metabolism of other barbiturates, which suggested to them that animals become tolerant to oxybarbiturates because of an accelerated metabolism due to pharmacologically inactıve metabolites ${ }^{29}$ This explanation may also apply to the observation by Dundee of acquired tolerance for thiobarbiturates that occurs with the administration of narcotic analgesics which was mentioned above ${ }^{30}$

The normal response to inhalation anaesthesıa by methohexital-resistant rats is even more perplexing Perhaps it can be explained as follows either that this barbiturate is metabolized and/or is excreled sufficiently at the time of the inhalation anaesthetic that there is no depressant activity remaining to alter the normal response, or that a longer, mild general depression persists from the barbiturate allowing a smoother induction of anaesthesia to occur with the inhalation of a small amount of diethyl ether or methoxyflurane Since there was no appreciable difference in the duration of mantenance of anaesthesia, one would then have to surmise that the sensitivity to the inhaled anaesthetic was increased A more plausible explanation for the observed effect is that the inhalation agent is handled quite differently from the oxybarbiturate by the hody and the excretory systems involved do not affect one another In any case, the effect of the interaction of an inhalation agent with a very short-acting barbiturate, in a subject who has developed resistance to the latter, rarely presents a clinical problem that cannot be solved merely by giving more of the barbiturate until the subject is rendered unconscious, and then adding the necessary amount of the inhalation agent to maintain an appropriate level of anaesthesia

The only consistent change that we observed, in this series of experiments, upon which there seems to be general aggreement is the apparent resistance to induction of inhalation anaesthesia during the early stages of the development of tolerance to ethanol and narcotic analgesics There is no simple explanation for this phenomenon, but a satisfactory one is that both ethanol and narcotic analgesics in low concentration in the blood cause excitement by depressing the higher brain functions that ordinarily irihibit the appearance of an offensive or belligerent behaviour response to stress. The excitement seen in an intoxicated individual is quite similar to that seen often durng the stage of delinum in the inmodified induction of diethyl ether andesthesia Guedel described this as the dream stage of anaesthesia "it represents the period of earliest loss of con$\$$ crousness, with the higher or control cerebral centers abolished, leaving the secondary centers free to run rot It is a potential danger stage in every general anaesthestic Nervous response to stimulation or to concurrent dieams is exaggerated and is often expressed in more or less violent physical activity" 40 The same explanation may be applied to the response to methoxyflurane, although the excitement stage during induction with 1 his agent is less dramatic When the latent release phenomenon has been accomplished by regularly inbibing a substantial amount of ethanol or injecting large doses of naicotics, the stage is 
already set for the overt response so that a stormy induction of anaesthesid with drethyl ether becomes the rule At a later stage of tolerance or addiction, the over-all depressant effect of the drug becomes dominant, and excitement| with an inhalation anaesthetic is then less likely to occiur and, instead, a lethal effect of the drug combinations becomes more likely owing to delayed metabolism of one or both depressant drugs, or to an existung high plasma level of the drug to which the subject has developed a tolerance

The effect which we observed that is different from that mentioned in previous reports is the greater susceptibility to a very short-actung barbiturate after tolerance has been established to a narcotic analgesic, rather than increased resistance Since we used dufferent drugs (dihydromorphinone and methohexital) the opposite response that was observed here points to the need for testing various drug combinations, particularly when the chemical structures of the various drugs have umportant differences

\section{Summary and Conclusions}

The responses of over 250 rodents made tolerant in groups to ethanol, dihydromorphinone $\mathbb{H C l}$, and methohexital were evaluated during the administration of approximately 2000 individual general anaesthetics in order to identufy the effects of the interaction of addicting sedative-type drugs and the general anaesthetics at various stages in the development of tolerance

Rats were made ethanol-tolerant in two ways by dally intrapentoneal injectrons with weekly increases in the dose, and by adding ethanol to the drinking water, which was rendered progressively more alcoholic The addition of ethanol to the drinking water was found to be the more satusfactory way of producing ethanol tolerance in rats because oral intake nore closely simulates clinical conditions for developing tolerance and it is attended by a lower mortality

Durng the development of ethanol tolerance, rats have a stormy and somewhat prolonged induction time with diethyl ether and methoxyflurane anaesthesia, whereas the duration of anaesthesia with these two agents does not appear to be affected After ethanol tolerance is established, the induction time with the inhalation anaesthetics is no longer affected

Ethanol-tolerant rats seem to be slightly resistant to the onset of anaesthesia after intraperitoneal administration of methohexital or thiopental This response is not evident when methohexital is combined with Innovar Rats then appear to be rather more sensitive than resistant during the mantenance of thropental anaesthesia, whereas they tend to recover a little faster when they are given methohexital However, the biological variation is so great that it is impossible to predict an individual response to the very short-acting barbiturates from these experments, and it is likely that established ethanol tolerance has in fact no appreciable influence on the induction or mantenance response to thiopental, methohexital, and Innovar

"Morphimism" in mice is produced satisfactorily by adding the narcotic analgesic to the milk provided for oral feeding $\mathbb{I}$ ihydromorphinone $\mathbf{H C l}$ addiction in mice causes slight resistance to induction of anaesthesia with diethyl ether, 
whereas they seem to be somewhat more sensitive to methoxyflurane and much more sensitive to methohexital anaesthesia The altered responses to general anaesthesia by mice tolerant to dihydromorphmone $\mathrm{HCl}$ as compared with noimal mice disappears when the narcotic is withdrawn

Prolonged methohexital pretreatment of rats causes no appreciable change in their response to general anaesthesia with diethyl ether or methoxyflurane even though the rats become quite resistant to this oxybarbiturate

In this study, we paid special attention to the effect of tolerance to three chemically different kinds of sedative-type drugs on the speed and duration of depression by general anaesthetics Although some degree of antagonism and synergism with anaesthesia was observed during the development of tolerance and habituation, as noted above, we have hittle unequivocal knowledge concerning the mechanısm by which these interactions were brought about

The simple explanation of the interaction of ethanol and diethyl ether being merely an additive synergism applies only before ethanol tolerance develops because progressive acute intake of ethanol by itself usually mimics the signs of a slow induction of general anaesthesia, as described by Guedel for diethyl ether The first effect with ether in the unpremedicated subject is observed as a change in the cortical control of behaviour There is then a gradual descent of the depression to envelop the entire brain, including the medulla When the medullary effects set in, respiratory, cardiovascular, and vasomotor functions are characteristically depressed The general effect of deep ethanol coma is then viltually the same as that of diethyl ether dnaesthesid and both undoubtedly have a marked depressant effect on synaptic transmission in the cortex of the brain, the reticular system, and the peripheral nervous system The metabolic effects of ethanol depression and diethyl ether anaesthesia are also rather similar Both cause a deciease in the alkalı binding power of the blood and the accumulation of lactic acid, and both show manifestations of a similar metabohc disturbance during recovery, marked by hangover, nausea, emesis, and thirst One would expect, therefore, that it these two agents were given to a patient at the same time, the manifestations of an additive synergism would be apparent, and this is actually what is seen However, once ethanol tolerance is developing, only the initial excitement stage with diethyl ether is exaggerated while the maintenance of anaesthesia is not obviously affected The response to methoxyflurane appears to be similarly affected, while the response to barbiturate anaesthesia is virtually unaffected

Much work is still in progress in an attempt to explain the basic mechanism of addiction to narcotic analgesics The development of tissue immunity is the favoured explanation It appears that the reaction of the narcotics addict to general anaesthesid with diethyl ether and methoxyflurane would be much the same as that for the alcoholic On the other hand, there seems to be some uncertainty as to whether the narcotics addict is more sensitive or more resistant to barbiturate anaesthesia From these experiments it seems that increased sensitivity should be expected with oxybarbiturates

It may remain difficult to explain changes that might occur after resistance or tolerance develops to a barbiturate until we can define in detal the changes 
in rate of absorption, distribution, and metabolyc degradation characteristic for each of the many chemical arrangements these drugs take New work in the past few years seems to indicate that rapid metabolic breakdown to inactive compounds is part of the mechanism for the apparent development of resistance with the oxybarbiturates For the present, one has little to fear from interactions between barbiturates to which tolerance has developed and inhalation anaesthetics, since the occurrence of barbiturate resistance does not appear to have any appreciable effect on the course of an inhalation anaesthetic

"It a drop of water falls on the surface of the sea|just over the flower-like disc of a sea-anemone, the whole animal contracts vigor busly If then, a second drop falls within a few minutes of the first there is less contraction, and finally, on the third and fourth drop, the response disappears altogether Here, in this marme polyp, is clearly exhibited one of the most persuasive phenomena of the animal kingdom-decrement of response with repeated stimulation" This observation by Sharpless and Jasper ${ }^{41}$ is fundamental to the broad understanding of habituation and drug tolerance In almost every case where the corticoreticular system is subjected to monotonous stimulation or is subjected to recurring serisory deprivation, the initial response is eventually suppressed and then disappears, while new types of stimulation on stress are handled in the usual way, because the organism has not as yet developed a feedback contiol of input for the new strmulus This is perhaps an oversimplified explanation of all the responses we observed above in drug-tolerant rodents that were subjected to general anaesthesia, but it seems to explain most of the effects that were observed

\section{RÉSUME}

Nous avons évalué les réponses de 250 1ongeurs, rendus tolérants par groupes à l'éthanol, au chlorhỹdrate de dihydromorphinone et au méthohexital, au cours d'approximativement 2000 anesthésies générales individuelles dans le but d'identuier les effets de l'interaction des médicaments type-sédatıfs créant une habitude et les anesthésiques généreaux à différents stades de développement de la tolérance

Nous avons eu recours à deux procédés pour rendre les rats tolérants à l'ethanol en pratiquant des injections intrapéritonéales quotidiennes d'éthanol et en augmentant la dose à toutes les semaines, puis, en ajoutant de l'éthanol à l'eau pour borre et en rendant cette eau progiessivement plus alcoolique L'addition d'éthanol à l'eau pour boire s'est avérée une façon plus satısfaisante de produre chez les rats une tolérance à l'éthanol parce que l'absorption par la bouche ressemble davantage aux conditions clinques de développement de tolérance et l'on observe un taux inférieur de mortalité de cette façon

Au cours du développement de la tolérance à l'éthanol, les rats soumıs à une anesthésie à l'éther diéthylique et au méthoxyflurane sont agités à l'unduction et celle-c1 est un peu plus prolongée, mars la durée de l'anesthésie avec ces deux agents ne semble pas être affectée Une fors la tolérance à l'éthanol bien établie, la durée de l'induction avec les anesthésiques par inhalation n'est plus influencée

Les rats tolérants à l'éthanol semblent légènement résistants à l'induction de 
l'anesthésie après l'adminıstration dans la cavité péritonéale de méthohexital ou de thiopental On n'observe pas cette réponse lorsque le méthohexital est associé à l'mnovan A ce moment-là, les rats semblent devenir au contrarre plus sensibles que résistants durant le maintıen de l'anesthésıe au thiopențal, alors qu'ils semblent se réveiller un peu plus rapıdement lorsqu'ils reçoıvent du méthohexital Toutefois, la variation biologique est si grande qu'il est impossible de prédire, d'après ces expériences, une réponse indıvıduelle à des barbituriques à actıon très courte et, selon toute apparence, la tolérance étable à l'éthanol n'a, en fait, aucune influence appréciable sur l'induction ou sur le maintien de l'anesthésie au thiopental, au méthohexital et à l'innovan

On produit le morphınısme de façon satısfaısante chez la sourıs en ajoutant ce narcotique analgésıque au lait donné pour l'alımentation L'habitude au chlorhydrate de dihydromorphınone chez la sourıs augmente légèrement la résistance à l'induction de l'anesthésie avec l'éther diéthylıque, alors que les mêmes souris semblent un peu plus sensibles au méthoxyflurane et beaucoup plus sensibles à l'anesthésıe au méthohexital Les réponses modifiées à l'anesthésie générale, chez les sourıs tolérantes au chlorhydrate de dihydromorphinone comparées aux sourıs normales, disparaissent si le narcotique est discontınué

Chez les rats, un traitement prolongé au méthohexital n'apporte aucun changement appréciable à leurs réponses à l'anesthésıe générale avec l'éther diéthylique ou le méthoxyflurane bien que les rats deviennent complètement résistants à cet oxybarbiturique

$\mathrm{Au}$ cours de cette étude, nous avons porté une attention spéciale à l'effet de la tolérance à troıs sortes chimıquement différentes de médıcaments typesédatifs sur la vitesse et la durée de dépression par les anesthésıques généraux Bien que nous ayons observé un certain degré d'antagonisme et de synergisme avec l'anesthésie au cours du développement de la tolérance et de l'habitude, tel qu'il est mentıonné cı-dessus, nous possédons peu de notıons précises sur le mécanısme qui engendrerait ces interactions

La simple explication de l'interaction de l'éthanol et de l'éther diéthylique étant simplement un synergisme d'accoutumance ne s'applique qu'avant le développement de la tolérance à l'éthanol car, en sol, l'absorption rapide et progressive d'éthanol ne fait habituellement que répéter les signes d'une induction lente d'anesthésie générale, tels que décrits par Guedel pour l'éther diéthylique Chez le sujet non prémédıqué, le premier effet que l'on observe avec l'un ou l'autre est un changement dans le contrôle cortical du sujet Puis, ll se fart une dépression graduelle descendante quı envahit tout le cerveau, y compris la molle Lorsque les effets médullaires apparaissent, les fonctions respiratoures, cardıo-vasculaires et vaso-motrıces sont déprımées de façon caractérıstıque L'effet général du coma profond produit par l'éthanol est alors virtuellement le même que celuı de l'anesthésie à l'éther diéthylıque et, sans aucun doute, les deux exercent un effet dépresseur marqué sur la transmission synaptıque dans le cortex cérébral, le système rétıculé et le système nerveux périphérique Les effets métaboliques de la dépression à l'éthanol et de l'anesthésie à l'éther diéthylique sont d'autre part assez semblables Les deux produisent une dimmution du pouvoir de fixation des alcalıs du sang et l'accumulation d'acide lactique, les deux, au cours du réveil, donnent des marifestatıons de troubles métaboliques 
semblables, soit du "hangover," soit des nausées, sort des vomissements ou de la soif On s'attendrait, en conséquence, à voir l'administration sımultanée de ces deux agents produre les manifestations d'un synergisme d'accoutumance et, de fait, c'est ce que nous observons Toutefors, lorsque la tolérance à l'éthanol est en cours, il y a seulement le stade initial d'excitation qui est exagéré avec l'anesthésie à l'éther diéthylıque alors que le maintıen de l'anesthésie n'est pas modıfié de façon manıfeste La reponse au méthoxyflurane semble être influencée de la même façon alors que la réponse à l'anesthésıe aux barbiturıques demeure virtuellement inchangée

Nous avons encore beaucoup de travaux en cours pour essayer de trouver une explication au mécanisme de base de l'habitude aux narcotiques analgésiques Le développement d'une immunité tissularre est notre explication favorite Il semble que la réaction du narcomane à l'éther diéthylıque et au méthoxyflurane ressemblerait beaucoup à la réactıon de l'alcoolıque à ces anesthésıques D'autre part, il semble exister un certain doute à savoir si le narcomane est plus sensıble ou plus résistant aux barbituriques De ces expériences, il semble qu'il faille s'attendre à une sensibilité accrue avec les oxybarbituriques

Il peut demeurer difficile d'expliquer les changements qui pourraient survenir une fors que la résistance ou la tolérance est acquise à un barbiturique, tant que nous ne pourrons pas définir en détall les changements dans le rythme d'absorption, la distribution et la dégradation métabolıque caractéristıques pour chacun des nombreux arrangements chımıques que ces médıcaments peuvent prendre Des travaux récents nous portent à croire qu'il s'opère une décompositıon métabolique rapide en produits inactıfs et que cela fait partıe du mécanısme du développement apparent de résistance avec les oxybarbituriques Pour le moment, il n'y a rien à craindre des interactions entre les barbituriques auxquels on s'est habitué et les anesthésıques généraux par ınhalatıon, puisque la présence de la résistance aux barbiturıques ne semble exercer aucun effet appréciable sur l'induction et le maintien de l'anesthésie par inhalation.

"Si 'une goutte d'eau tombe à la surface de la mer au-dessus du disque en forme de fleur de l'anémone de mer, tout l'anımal se contracte vigoureusement $\mathrm{S}$, au bout de quelques minutes, ll tombe une deuxième goutte, la contraction est plus farble et, finalement, à la troısıème et à la quatrième goutte, la réponse disparaît progressıvement Voilà, manifesté clairement chez ce polype main, le phénomène le plus convaincant du règne anmal-dımınution de la réponse devant une stumulation répétée" Cette observation de Sharpless et jasper ${ }^{41}$ demeure fondamentale pour se faure une idée de l'habitude et de la tolérance aux médıcaments Dans presque tous les cas où le système cortıco-rétıculé est soumis à une stımulation monotone ou à une privation répétée de sensations, la réponse initiale est supprimée éventuellement, puis elle disparaît, alors que de nouvelles varıétés de stımulation ou d'agressıon sont reçues de façon normale parce que l'organısme n'a pas encore développé un contrôle de renseignements en sens inverse pour l'arrivée d'un nouveau stımulus Voilà une explication peutêtre trop simplifiée de toutes les réponses auxquelles nous avons fait allusion antérieurement chez les rongeurs tolérants aux médicaments que nous soumettons à l'anesthésie générale, mais cela semple expliqueı la plupart des effets qu'il nous a été donné d'observer 


\section{REFERENCES}

1 LeE, J A Synopsis of Anesthesıa, p. 460 4th ed, Baltımore, Md W/lliams \& Wilkıns (1959)

2 Searles, P W \& Lundy, J S Anesthesiology (ed D E Hale), p 149 et seq 2nd ed, Philadelphıa F A Davis Co (1963)

3 Abreu, B E \& Emerson, G A Susceptibility to Ether Anesthesia of Mice Habituated to Alcohol, Morphine or Cocaine Anesth \& Analg 18294 (1939)

4 Green, M W \& Koppanyi, T Studies on Barbiturates XXVII Tolerance and Cross Tolerance to Barbiturates Anesthesiology 5,329 (1944)

5 DundeE, J W Thiopentone and Other Thiobarbiturates, p 121 Edinburgh E \& S Livingstone, Ltd (1956)

6 Moyers, J \& Thayer, C B Anesthetic Effects of Chronic Alcohol Ingestion in Dogs Proceedings, First European Congress of Anesthesiology of the World Federation of Societies of Anesthesiologists, Vienna (1962)

7 Shuster, L, Hannam, R V , \& Boyle, W E, Jr A Simple Method for Producing Tolerance to Dihydromorphinone in Mice J Pharmacol \& Exper Therap 40149 (1963)

8 Seevers, $\mathrm{M} \mathrm{H}$ Adaptation to Narcotics Fed Proc 13672 (1954)

9 Wikler, A Opiate Addiction Springfield, Illmo1s C C Thomas (1953)

10 Melville, K I, Joron, G, \& Douglas, D Combined Alcohol and Glutethimide or Secobarbital Central Nervous System Depression Proc Canad Fed Biol Soc (June, 1962)

11 Ecrola, $R$ The Effect of Ethanol on the Toxicity of Promazme, Chlorpromazine, Promethazıne and Hydroxyzine Acta Anaesth Scand 787 (1963)

12 Dille, J M - \& Amlquist, R P The Synergism of Ethyl Alcohol and Sodium Pentobarbital J Pharmacol \& Exper Therap 61.385 (1937)

13 Ramsey, $H$ \& HAAG, $H$ B The Synergism between the Barbiturates and Ethyl Alcohol J Pharmacol \& Exper Therap 88 313 (1946)

14 Smith, J N \& Loomis, $T$ A The Potentiating Effect of Alcohol on Thiopental Induced Sleep Proc Soc Exp Biol NY 78827 (1951)

15 SandBurg, F A Quanitative Study on the Alcohol-Barbiturate Synergism Acta Physiol Scand 22311 (1951)

16 Gruber, C M A Theoretical Consideration of Additive and Potentiated Effects between Drugs with a Practical Example using Alcohol and Barbiturates Arch Int Pharmacodyn 10217 (1955)

17 Thompson, G N Alcoholism Springfield, Illinors C C Thomas (1956)

18 Himwich, H E The Physiology of Alcohol, J A M A 163545 (1957)

19 Veldstra, H Synergism and Potentiation Pharmacol Rev 8339 (1956)

20 Oberst, F W Free and Bound Morphine in the Urıne of Morphine Addicts J Pharmacol \& Exper Therap 69240 (1950)

21 Eckenhoff, J E \& Oech, S R The Effects of Narcotics and Antagomsts upon Respiration and Circulation in Man Clin Pharmacol \& Therap 1483 (1960).

22 Dobkin, A B \& Criswick, V G Circulatory Response to Tilt with Narcotic Analgesics in Normal Healthy Male Subjects Anesthesiology 22398 (1961)

23 Dobkin, A B Prolongation of Thiopental-Induced Sleep in Dogs by Narcotic Analgesics Anesthesiology 22291 (1961)

24 Woons, L A Identification of Morphine Glucuronide as Metabolite in Dog Ble and Urine Fed Proc 13419 (1954)

25 Woods, L A, Cochun, J, Fornfeld, E G , \& Seevers, M H Estimation of Morphine in Biochemical Materials J Pharmacol \& Exper Therap 11164 (1954)

26 Cochin, J, Haggart, J, Woods, L A, \& SeEvers, M H Plasma Levels, Uninary and Fecal Excretion of Morphine J Pharmacol \& Exper Therap 11174 (1954)

27 Seevers, $M$ H \& Woods, L A The Phenomenon of Tolerance Am J Med 14546 (1953)

28 Burns, J J , Berger, B L, Lief, P A, Wollack, A, Papper, E M, \& Brodie, B B Physiological Disposition and Fate of Meperidine (Demerol) in Man and a Method for Its Estımation in Plasma J Pharmacol \& Exper Therap 114289 (1955)

29 Burns, J J Role of Biotransformation, in Uptake and Distribution of Anesthetic Agents (ed ) E M Papper \& R J Kitz Toronto McGraw-Hill (1962) 
30 Dundee, J W Acquired Tolerance to Intravenous Thiobarbiturates in Anmals Brit J Anaesth 27165 (1955)

31 Brodie, B B, Mark, L C, Papper, E M, Lief, P A , Beirstein, E, \& Rovenstine, E A The Fate of Thiopental in Man and a Method for its Estimation in Biological Materials J Pharmacol \& Exper Therap 9885 (1950)

32 Brand, L, Mazzia, V D B, VanPoznak, A Bunns, J J, \& Mark, L C Lack of Correlation between Electro-encephalographic Effects and Plasma Concentrations of Thiopentone Brit J Anaesth 3392 (1961)

33 Brodie, B B, Mark, L C, Lief, P A, Bernsilein, E, \& Papper, E M Acute Tolerance to Thiopental J Pharmacol \& Exper Therap 102215 (1951)

34 Dundee, J W, Price, H L, \& Dripps, $R$ D Acute Tolerance to Thiopentone in Man Brit J Anaesth 28344 (1956)

35 DundeE, J W A Method for Determining the Duration of Thiopentone Narcosis in the Dog Brit J Anaesth 25291 ( 1953)

36 Hubbard, $T$ F \& Goldbaum, $L \mathbb{R}$ The Mechanism of Iolerance to Thiopental in Mice I Pharmacol \& Exper Therap 97488 (1949)

37 Dobmin, A B \& Wyant, G M The Physiological Effect of Intravenous Anaesthesia on Man Canad Anaesth Soc J 4295 (1957)

38 Egbert, L D, Oech, S R, \& Ecrenhorf, J E Corapars on of the Recovery fiom Methohexital and Thropental Anesthesia in Man Surg Gynec \& Obst 109427 (1959)

39 Fraser, H F \& Isbeli, H Chronic Intoxication of Dogs with Sodium Barbital Fed Proc 13355 (1954)

40 Gueder, A E Inhalation Anesthesı-A Fundamental Gulde New York The MacMillan Co $(1937)$

41 Sharpless, $\mathrm{S}$ \& Jasper $\mathrm{H} \quad \mathrm{H}$ Habituation of the Alousal Reaction Brain 79655 (1956) 